\title{
Research on the Present Situation of Soil Oil Pollution and Phytoremediation Technology in Northern Shaanxi
}

\author{
Wei Yang* \\ ${ }^{1}$ Institute of Land Engineering and Technology, Shaanxi Provincial Land Engineering Construction Group Co., Ltd., Shaanxi Key \\ Laboratory of Land Consolidation, Xi'an 710075, China \\ ${ }^{2}$ Key Laboratory of Degraded and Unused Land Consolidation Engineering, the Ministry of Natural Resources, Xi' an 710075, China \\ ${ }^{3}$ Shaanxi Provincial Land Consolidation Engineering Technology Research Center, Xi'an 710075, China
}

\begin{abstract}
Aiming at the prominent problem of soil oil pollution in northern Shaanxi, this paper comprehensively analyzed the current situation of soil oil pollution in northern Shaanxi, phytoremediation technology for polluted soil, and microbially enhanced phytoremediation technology. The analysis showed that with the continuous expansion of the scale of oil development, the oil pollution in northern Shaanxi is extremely serious, which makes the ecologically fragile areas face a severe test. In response to pollution problems, scholars have carried out extensive research on green remediation technologies such as suitable plants and microbial combined plants, and have accumulated certain research results, which provide technology support for establishing a phytoremediation scientific system suitable for the oil-polluted soil in the local environment of northern Shaanxi.
\end{abstract}

\section{INTRODUCTION}

The average annual oil output in the world is about 4 billion tons. Some statistics showed that $2 \mathrm{~kg}$ of pollutants enter the environment for every $1 \mathrm{t}$ of oil production on average. Therefore there are about 8 million tons of oil pollutants entering the environment every year. These pollutants will eventually enter the soil in multiple ways, causing pollution to the soil quality. Due to the large-scale demand for oil and its products, the soil and water environments of countries around the world are threatened by oil pollution to varying degrees. Northern Shaanxi is the birthplace of China's petroleum industry. The proven oil reserves of Yan'an in northern Shaanxi are 1.4 billion tons, and 360 million tons in Yulin. In recent years, with the continuous expansion of the scale of oil development, the environment in the ecologically fragile northern Shaanxi region is facing extremely severe tests, and the problems of pollution and ecological destruction have become increasingly serious $^{[1-2]}$.

The United States, Netherlands, Italy and other countries have carried out many years of research on the remediation of oil-polluted soil. More than 40 plants with the ability to degrade oil pollutants have been reported internationally, including willow, poplar, alfalfa, etc. ${ }^{[3]}$. China's research on phytoremediation of oil-polluted soil started relatively late. At present, phytoremediation has become the generally accepted technique of choice for contaminated soil remediation ${ }^{[4]}$. However, screening indigenous plants, cultivating repairing plants, and exploring the mechanism of restoration are still urgent issues need to be studied. This paper summarized the current situation of oil pollution in northern Shaanxi, and summarized the current status of plants and plant joint remediation technologies on local oil-polluted soil, with a view to providing theoretical support for the local oil-polluted soil remediation.

\section{STATUS OF SOIL OIL POLLUTION IN NORTHERN SHAANXI}

In the process of oil extraction, smelting, transportation, processing, etc., pollution problems of varying degrees will be caused (Fig. 1). According to relevant literature and information, the area of oil-polluted soil in northern Shaanxi has exceeded $70,800 \mathrm{~km}^{2}$, and is increasing at an alarming rate of $1.67 \%$ per year. The content of total petroleum hydrocarbons (TPHs) in the soil has reached $5 \sim 60 \mathrm{~g} \mathrm{~kg}^{-1[5]}$. Another study showed that in 2000 alone, the annual output of ground crude oil and sludge in Yan'an reached 20,000 tons, and the annual discharge of drilling and oil production wastewater exceeded 800,000 tons $^{[6]}$. Some researchers have monitored the oil pollution of the soil near an oil well in Yulin, and the results showed that the total petroleum hydrocarbon concentration at $12 \sim 16 \mathrm{~cm}$ below the surface exceeds 20 $\mathrm{g} \mathrm{kg}^{-1[7]}$. Zhang Xiaoyang et al. tested the soil around 8 oil wells in Ansai County and showed that the total petroleum hydrocarbon content ranged from 0.08 to $71.49 \mathrm{~g} \mathrm{~kg}^{-1[8]}$. The most polluted areas are $0 \sim 5 \mathrm{~m}$ and 5 20 m outside the well site. Monitoring of oil wells in Ansai and Yanchang in northern Shaanxi showed that the total petroleum hydrocarbon content in the surface soil at

\footnotetext{
* Corresponding author: weiyang1120@163.com
} 
0 20 cm was significantly higher than that in the bottom. The surface layer content is 3.1 61.7 times the critical value $\left(500 \mathrm{mg} \mathrm{kg}^{-1}\right)$, which indicateed that the petroleum hydrocarbon contamination in the soil in this region is particularly serious, and the restoration is imminent ${ }^{[9]}$. Oil pollution in northern Shaanxi not only causes loss of farmland productivity, but also severely affects the local people 's production and life. The average value of environmental damage caused by oil pollution in northern Shaanxi is 8.551 billion yuan, and it is urgent to study repair technologies that meet local soil conditions and ecological environment.

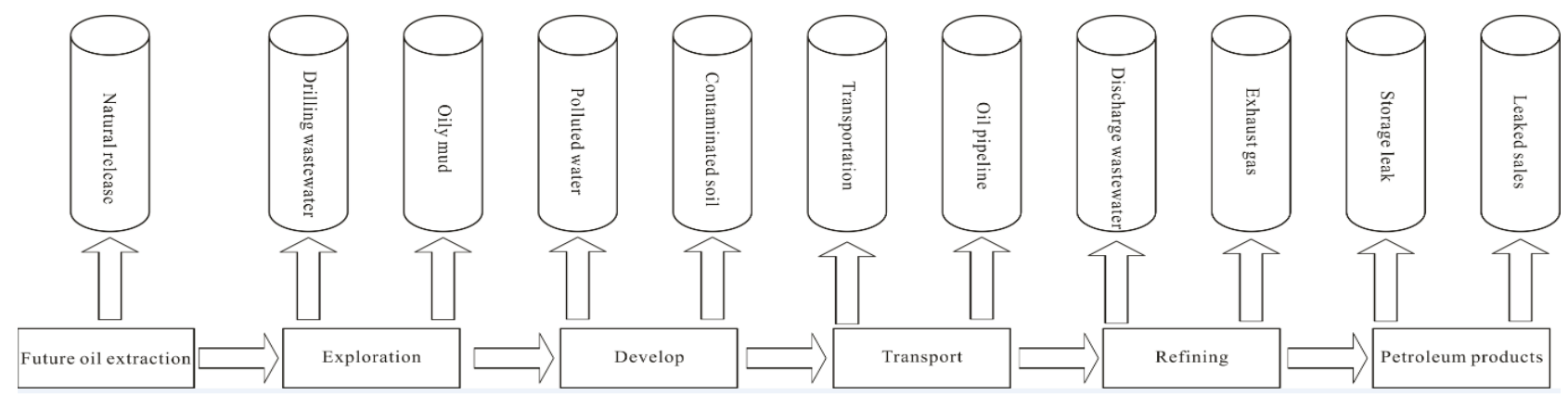

Fig.1 Schematic diagram of petroleum process and waste discharge ${ }^{[10]}$

\section{PHYTOREMEDIATION OF OIL-POLLUTED SOIL IN NORTHERN SHAANXI}

\subsection{Phytoremediation mechanism}

Phytoremediation technology is one of the cheapest remediation technology. It is a kind of green remediation technology that uses suitable plants to repair and eliminate pollutants in the soil. Phytoremediation is mainly based on the interaction between plants and the polluted soil environment, so that plants can reduce the concentration of pollutants in the soil through absorption, degradation, transfer, volatilization and other methods, thereby achieving soil purification ${ }^{[11-12]}$. Phytoremediation can be used for the treatment of organic pollutants such as petroleum in the soil, mainly because plants can directly absorb organic pollutants and undergo metabolic transformation in their bodies. On the other hand, plant roots will change the physical and chemical properties of the soil. At the same time, root exudates will strengthen the degradation and transformation of organic pollutants by microorganisms in the soil, thereby effectively promoting the decomposition and transformation of pollutants ${ }^{[5,13]}$. Since the 1980 s, phytoremediation has become more and more popular because it makes up for the disadvantages of microbial repair technology. Phytoremediation has the characteristics of low cost, simple implementation, non-destructive soil structure, environment-friendly and beautiful appearance. In addition, the growth of roots and stems of plants, the absorption of nutrients, and the decomposition of plants have a positive effect on the physical, chemical, and biological properties of the surrounding soil environment, which has greatly improved the soil environment.

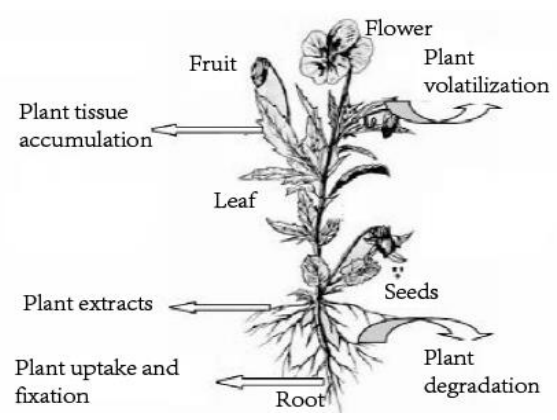

Fig. 2. Mechanism of phytoremediation of oil-polluted soil [5]

\subsection{Phytoremediation technology}

Although China's research on soil oil pollution started late and there are few studies on northern Shaanxi, after recent developments, scholars have accumulated some research results on phytoremediation of petroleum contaminated soil in northern Shaanxi. Some researchers have selected six types of suitable legumes from northern Shaanxi to conduct oil pollution soil remediation research. The results showed that Loessial soil-alfalfa-low concentration pollution and Loessial soil-acacia-high concentration pollution are two combinations with potential for remediation ${ }^{[14]}$. Studies by Qi et al. Showed that the growth of plants can significantly increase the rate of oil degradation in soil. The degradation rates of alfalfa and sweet clover were $26.98 \% \sim 39.72 \%$ and $21.64 \% \sim 47.99 \%$, which were 1.3 2.5 times and 1.5 2.5 times than that of control, respectively. These two plants have the potential to repair soils with oil concentrations below $17 \mathrm{~g} \mathrm{~kg}^{-1}[15]$.

Some studies have pointed out that shrubs such as pecans, amorpha, alfalfa, and erect milkvetch can play a greater advantage in removing oil pollutants from soil ${ }^{[16]}$. Zhang et al. used the plant's oil content, pollutant transfer, and absorption capacity as indicators, and screened robinia pseudoacacia, platycladus orientalis, populus simonii, amorpha fruticosa, sophora, hippophae rhamnoides, agropyron, and artemisia annua in northern 
Shaanxi as indicators Plants for soil repair ${ }^{[9]}$. Wei et al. selected six species of north Shaanxi suitable plants for remediation experiments. The results showed that the plants have different remediation potentials in soils with different pollution levels. Among them, ryegrass, tall fescue, wheatgrass, alfalfa, erect milkvetch, and caragana have the potential to repair oil-contaminated soil below $0.5 \%$; tall fescue, ryegrass, wheatgrass and alfalfa have the potential to repair soil below $1 \%$ contaminated level; ryegrass, tall fescue and wheatgrass have the potential Potential for remediation of soils below $4 \%$ pollution level ${ }^{[17]}$. Yu et al. (2015) collected 19 kinds of common urban greening trees withered leaves in northern Shaanxi and conducted oil contaminated soil remediation tests, and comprehensively evaluated the effects of different trees withered leaves on oil-contaminated soil remediation. The results showed that melia azedarach and other seven kinds of litter had better comprehensive restoration effects, while other litter restoration effects were not obvious, and even played a certain adverse effect ${ }^{[18]}$.

\subsection{Phyto-microbial repair technology}

Microbial degradation is generally based on soil pollution conditions, enrichment and domestication of indigenous microorganisms in polluted soil, or artificial inoculation of highly effective microorganisms with degradability. The microbial life activity breaks the chain of petroleum substances and decomposes into harmless substances with low molecular weight ${ }^{[13]}$. It has been reported that there are 70 genera of microorganisms that can degrade petroleum hydrocarbons (including 28 genera of bacteria and 30 genera of fungi), with a total of more than 200 species $^{[19]}$. Compared with physicochemical repair technology, the repair efficiency of bioremediation technology is generally lower, but the plant-microbe combination can greatly enhance the repair efficiency of the two applied separately.

Some researchers have combined rhizobium, petroleum hydrocarbon-degrading bacteria, and lentils to repair oil-polluted soil, and the petroleum hydrocarbon degradation rate of soil has reached $83.05 \%$, which showed that the combined plant-microbe repair can effectively improve the petroleum hydrocarbon degradation capacity ${ }^{[20]}$. Deng et al. also showed that when soybeans are grown on polluted soil, the rate of petroleum degradation by adding nitrogen-fixing bacteria, phosphorus-decomposing bacteria, ACC deaminase-producing bacteria, and $\mathrm{H}_{2} \mathrm{O}_{2}$ was $22.35 \%$ higher than that of the plant-only control group ${ }^{[20]}$. Some researchers have used indigenous microorganisms to combine plants to repair oil-polluted soil. The results showed that the combination of tall fescue, JQ1 and JQ2 has the largest degradation of petroleum hydrocarbons in the soil, with a 30 -day degradation rate of $49.81 \%$, and the number of rhizosphere microorganisms was corresponding 1 2 orders of magnitude higher, the FDA activity of microorganisms was $0.53 \sim 1.26$ times higher ${ }^{[21]}$. Studies by Lin et al. showed that with $\mathrm{K}_{2} \mathrm{HPO}_{4}$ as the phosphorus source, the alfalfa + JQ_1 + JQ_2 combination with $\mathrm{NH}_{4} \mathrm{Cl}$ and the small crown flower+JQ_1+JQ_2 with $\mathrm{NH}_{4} \mathrm{NO}_{3}$, the could petroleum hydrocarbons degradation rate have reached $45.1 \%$ and $47.1 \%$, respectively ${ }^{[22]}$.

\section{CONCLUSIONS}

For northern Shaanxi, scholars have carried out extensive research and selected a variety of plants, such as herbs and woody plants, for remediation of oil-polluted soil. At the same time, combining plants with microbial repair technologies has greatly improved pure plant repair efficiency. From a practical point of view, although the scholars' research work is very active and has achieved outstanding results, the research results that are actually applied to production practice are still few. Regarding the large-scale application of oil-polluted soil remediation technology in northern Shaanxi, much work still needs to be explored by soil scientists and environmental scientists. This will provide support for the establishment of a phytoremediation scientific system suitable for the oil-polluted soil in the northern Shaanxi.

\section{Acknowledgements}

This study was supported by the Fundamental Research Funds for the Central Universities of China (CHD300102279501).

\section{References}

1. Shi HX. The research on the transport regularity of petroleum in the loess plateau. Xi'an University of Architecture and Technology, Xi'an, (2001)

2. Sun NS. \& Zhou J. Investigation and prevention countermeasures of oil extraction pollution in Yan'an. Shaanxi Environment, 8(1), 11-12, (2001)

3. Liu WX., Luo YM., Wang DX. Advances and prospects in remediation technology and large-scale applications for petroleum contam inated soil. Environmental Monitoring Management and Technology, 23(3), 47-51, (2011)

4. Kamath R., Rentz, JA., Schnoor JL., et al. Phytoremediation of hydrocarbon-contaminated soils: principles and applications. Studies in Surface Science \& Catalysis, 151(6), 447-478 (2004)

5. Wang GF., Wang JC., Jing MB. Research progress on soil oil pollution and bioremediation technology in the Loess Plateau. Journal of Anhui Agricultural Sciences, 45(32), 65-70 (2017)

6. Shi HX., \& Huang TL. Experimental study on the adsorption characteristics of petroleum pollutants by soil in the loess region. Environmental Science and Technology, 25(3), 10-12 (2002)

7. Zhang Y. Current situation and techniques of remediating of petroleum contaminated soils of the loess area. Journal of Shangluo University, 22(2), 56-58, (2008)

8. Zhang XY., Li KR., Zhang LJ. Effects of petroleum 
contamination on physical and chemical propertie of soils in oilfield of northern Shaanxi. Research of Soil and Water Conservation, 20(3), 32-38 (2013).

9. Zhang LJ., Li KR. Zhang XY. Absorption and accumulation of petroleum contaminats by different plants in the loess plateau. Journal of Northwest A \& F University (Nat. Sci. Ed.), (8), 118-124(2013)

10. Du WD., Wan YY., Zhong NN., et al. Current status of petroleum-contaminated soils and sediments [J]. Journal of Wuhan University (Nat. Sci. Ed.), 57(4):311-322(2011)

11. Kirk, JL., Klironomos JN., Lee H., et al. The effects of perennial ryegrass and alfalfa on microbial abundance and diversity in petroleum contaminated soil. Environmental Pollution, 133(3), 455-465(2005).

12. Liu SL., Luo YM., Ding KQ., et al. Phytoremediation of organic pollutants in soils. Soils,(03), 12-17,35(2003).

13. Lin X., Li PJ., Tai PD., et al. (2006). Research progress in phyto-microbial remediation of petroleum-contaminated soil. Chinese Journal of Ecology, 25(1), 93-100 (2006).

14. Shan BQ., Zhang YT., Cao QL., et al. Growth responses of six leguminous adaptable in northern Shaanxi to petroleum contaminated soil. Environmental Science, 35(3), 1125-1130 (2014)

15. Qi YC., Wang J., Tong YA., et al. Screening of weed plants for phytoremediation of petroleum-contaminated soils. Ecological Science, 34(1), 148-153(2015)

16. Shi TF., Liu ZW., Tian N., et al.. Potential influences of petroleum pollution on soil and legume shrubs and grasses in the loess area. Acta Agrestia Sinica, 21(2), 295-301 (2013)

17. Wei Y., Wang YQ., Duan M., et al. Growth Tolerance and Remediation Potential of Six Plants in Oil-Polluted Soil. Journal of soils and sediments, 19(1):373-380(2019)

18. Yu Q., Zhang XX., Liu ZW., et al. Remediation Effects of urban greening-tree litters on petroleum-contaminated soil in oil producing region of northern Shaanxi. Journal of Agro-Environment Science, 34(1), 50-57 (2015).

19. Ding KQ., Sun TH., Li PJ. Bioremediation of the soil contaminated by petroleum hydrocarbons. Chinese Journal of Ecology, 19(2), 50-55(2000)

20. Deng ZS., Tian XJ., He XL. et al. Experimental study on bioremediation of crude oil-contaminated soil in northern shaanxi oilfield. Environmental Engineering, 993-996 (2016)

21. Yang Q., Nie MX., Su JM., et al. Joint Action of tall fescue and fine bacterial floras to degrade hydrocarbons in yellow loessial oil-contaminated soils from Shanbei. Soils, 41(3) (2009)

22. Lin LN. Study on microbial-phytoremediation technology for petroleum-contaminated soil in northern Shaanxi. Xi'an University of Architecture and Technology, Xi'an, (2009) 